MACIEJ PIETRZAK

Instytut Filmu, Mediów i sztuk Audiowizualnych Uniwersytet im. Adama Mickiewicza w Poznaniu

\title{
David Avidan's Message from the Future. Nuclear fantasies of the galactic poet
}

\begin{abstract}
Pietrzak Maciej, David Avidan's Message from the Future. Nuclear fantasies of the galactic poet. "Images" vol. XXVIII, no. 37. Poznań 2020. Adam Mickiewicz University Press. Pp. 127-139. ISSN 1731-450X. DOI 10.14746/i.2020.37.07.

David Avidan's Message from the Future (1981) is one of few Israeli science fiction films ever made. This ambitious project of the well-known avant-garde poet has been forgotten for many years, as a result of a financial and artistic failure of the movie. The paper shows Avidan's doomed film as an interesting cultural text that can be read as the director's commentary on the Israeli reality of his time. Contrary to the artist's claims about the global ambitions of the picture, Message from the Future is immersed in the local, exploring it under the guise of narrative structures borrowed from Hollywood. The text analyzes a precise deconstruction of the plot patterns characteristic for the classic American SF films from the 1950s, which Avidan adjusted to the Israeli sociopolitical landscape at the turn of the seventies and eighties.
\end{abstract}

KEYworDS: David Avidan, science fiction, Israeli cinema, Israeli poetry, Cold War, nuclear weapon

"A science fiction sequence: a time-traveller from the future returns to the present with all World War Three data fully documented challenging everybody with a frightening suggestion - to have the war predated." [1] These words begin the poem Message from the Future, first published by David Avidan in 1978. Few readers of the time likely suspected that they had before their eyes not so much a poem, but rather an outline of a film script. The idea for an Israeli science-fiction film based on lines by an eccentric avant-garde poet must have seemed irrational enough to be difficult to imagine. After all, Hebrew culture and literature never abounded in science fiction visions of the future. The reason for this is believed to be, among other factors, the ideological attitude of the Zionist movement, which at its inception was reluctant to accept the dreamlike narrative offered by speculative literature. As Sheldon Teitelbaum and Emanuel Lottem pointed out, ideology required that the Zionist mission be presented with all the grit and realism that artists could muster.[2] Science fiction, fantasy and horror, associated with what is imagined and unreal, had for decades been treated with contempt and suspicion by the Israeli literary establishment.[3] It is not surprising, then, that these genres did not take firm root in Israel.[4]

[1] D. Avidan, Message from the Future, [in:] Futureman, ed. by T. Keller, Los Angeles 2017, pp. 135-136. [2] S. Teitelbaum, E. Lottem, Introduction, [in:] Zion's Fiction: A Treasury of Israeli Speculative Literature, ed. by S. Teitelbaum and E. Lottem, Simsbury 2018.
Images vol. XXVIII/no. 37

Poznań 2020

ISSN 1731-450x 
Similar phenomena also occurred in Israeli cinema, which for decades clung to formulas which were faithful to reality, very rarely departing from realism in favour of film experiments or conventions borrowed from Hollywood. As Eran Kaplan accurately concluded: "Even when Israeli filmmakers sought to ditch realism, to create art for the sake of art, reality proved, again and again, a gravitational field too strong for them to overcome". [5] The obstacles on the way to large-scale science-fiction film productions in Israel were not only of an ideological and cultural nature. It should be emphasized that for the vast majority of its existence, the Israeli film industry was extremely modest, and did not have access to the extensive technical and infrastructural facilities necessary to implement such projects. As a result, Israeli SF films were absent from Israeli cinema screens for many years. Relatively high financial requirements, together with the aforementioned attachment of Israeli filmmakers to realism, effectively blocked the possibility of making such films and reduced the subject of SF to a niche, which was composed mainly of shorts and student films.[6]

However, the impossible became a fact. In 1981, a film adaptation of the poem was released. David Avidan was not only the author of the literary original, but he also wrote the script, directed the film and even played one of the roles. Not surprisingly, the movie was widely commented on before its premiere. The bizarre picture appeared to be an artistic oddity, a project that did not suit Israeli preferences and habits. What also made the movie stand out was its production scale and international character. Set in 1985, the story of an alleged time traveller from the thirtieth century trying to persuade the nations of the world to unleash a global nuclear conflict in the name of a "better future" was at the time one of the most expensive films made in Israel. The momentum of the production could therefore make a fair impression, boldly emphasized by the director himself when he announced in the foreign press that: "[...] it is Israel's first SF film. More than that, it is the Middle East's... perhaps Asia's first SF film and most certainly the first independent SF film produced anywhere without backing from Hollywood or any major film companies in the world.[7] The director's exaggerated boasts are a good illustration of his artistic temperament and enormous ego, for which he was well known among his countrymen. Avidan was an artist whose ambitions reached far beyond Israel, and he considered the production of his first full-length film a chance to reach audiences around the world with his message. Therefore, almost the entire film was made in English, and its action takes place in several

were described in detail by Nachman Ben-Yehuda. N. Ben-Yehuda, Sociological reflections on the history of science fiction in Israel, "Science Fiction Studies" 1986, vol. 13, no. 38, pp. 64-78.

[5] E. Kaplan, Projecting the Nation. History and Ideology on the Israeli Screen, New Brunswick 2020, p. 9.
[6] Describing the panorama of Israeli SF works, Keren Omry points in this context primarily to short films by Rama Drimer, Doron Eran, Isaac Florentine, and Riki Shelach. - K. Omry, Israeli SF 101, "SFRA Review" 2013, no. 306, pp. 8-11.

[7] T. Crawley, Message from the Future, "Starburst Magazine" 1981, vol. 4, no. 3, pp. 16-18. 
countries around the world. In an interview given during the filming, the director clearly defined his artistic modus operandi: "My arena is the entire planet. [...] Israel is but a small piece of land. I don't work in Tel Aviv. I work from Tel Aviv." [8]

Contrary to Avidan's expectations, his science fiction picture was rejected by the public and critics, and the ambitious plans of the poet-director to reach foreign audiences with his message forever remained in the sphere of his unfulfilled desires. The Israeli press did not spare the director bitter words, accusing him of asking seemingly important, existential questions, when in fact offering viewers nothing but nonsense.[9] Others considered Message from the future to be intellectually primitive, and accused the director of racism, megalomania and rhetorical gibberish.[10] In encyclopedic publications devoted to the history of science fiction, we can find only a few references bluntly describing Avidan's picture as interesting though wordy[11] or execrable[12]. The gloomy course of events outlined above is completed by the very limited distribution of the movie, which was only shown to the public a few times and was then shelved to return to the broader circulation almost three decades later when the DVD edition was released.

Was the rejection of Avidan's film well-deserved? Was it just gibberish and pseudo-intellectual pulp? Well, it undoubtedly was not an artistic achievement, and the list of its weaknesses would be long. It is difficult not to notice the disastrous workshop layer of the movie, which consists of sloppy cinematography, uneven editing, terrible acting (with a strong Hebrew accent), wooden dialogue and omnipresent narrative chaos. Message from the future is, however, a film that cannot be ignored, a film which by its very originality demands a more in-depth analysis. In the following part of this paper, I will try to prove that Avidan's doomed film is an interesting cultural text that we can read as the director's commentary on the Israeli reality of that time. Contrary to the artist's puffy claims about the global ambitions of his picture, Message from the Future is in fact a film immersed in the local, exploring it under the guise of narrative structures borrowed from Hollywood. In the movie, Avidan made a precise deconstruction of the plot patterns characteristic for the classic American SF films from the 1950s, adjusting them to the Israeli sociopolitical landscape at the turn of the seventies and eighties, proving that a gravitational field was too strong to overcome even for him. These conscious artistic moves are worth exploring because they show that an apparently chaotic film devoid of any internal logic was constructed around specific themes that may seem incomprehensible without reference to the appropriate contexts.

[8] As cited in: A. Weisman, David Avidan: The Sadosemantic Poet, [in:] Futureman..., p. 9.

[9] T. Nativ, Avidan Magiya Min ha-atid, "Davar", 13.02.1981, p. 21.

[10] G. Manor, Mada Bizyoni, "Al HaMishmar", 10.09.1981, p. 6.
[11] P. Nicholls, The World of Fantastic Films, New York 1984, p. 203.

[12] S. Teitelbaum, Israel, [in:] The Encyclopedia of Science Fiction, ed. by J. Clute and P. Nicholls, New York 1993, p. 630. 
A Poet

from Another Planet
Before focusing on the main part of the argument, however, it will be necessary to briefly outline the creative profile of the artist behind this unusual project. Message from the future is an expressive example of authorial cinema, strongly marked by the personality and temperament of its creator, for whom the adventure with cinema was only one of many fields of activity. David Avidan was one of the most famous artists of his generation, who, almost from the beginning of his poetic career, looked for new areas of artistic expression that would allow him to escape the limitations and conventions imposed on him by poetry. The film was supposed to be a logical consequence of this path: an intense artistic experience that would impact the audience more than any poem.

Born in 1934, David Avidan represented one of the most influential generations in the history of Hebrew poetry. In the 1950s, the literary scene of Israel witnessed the emergence of poets who were to give the poetry of the young country a new neo-modernist face. Natan Zach, Moshe Dor, Yehuda Amichai, Aryeh Sivan and Avidan came to be referred to as The Statehood Generation (dor ha- medina), to distinguish them from earlier luminaries of Hebrew poetry. Young authors brought new energy to literature and rejected the influences of Central European symbolism, expressionism and socialist realism. Above all, they freed poetry from the collective spirit inherent in earlier generations of authors focused on the glorification of the Zionist mission and the national struggle for independence.[13] When Avidan's first book, Lipless Faucets, was published in 1954, the young poet became known as a controversial artist who did not avoid confrontation with social taboos and literary tradition. Brutal and sexual motifs, showing disgust towards the community and communal values, combined with a parodist attitude towards the poetic mainstream of the time, met with sharp criticism from the literary establishment, for which Avidan personified everything that was forbidden and deviant.[14] In the following years, the rebellious artist established his reputation as the enfant terrible of the Israeli poetry scene. He did not shy away from literary experiments and became famous as the inventor of a series of linguistic innovations that gave his poetry a unique avant-garde aesthetic.

One of the driving forces behind Avidan's work was an overwhelming desire to break free from the creative constraints imposed on him by literature. From the early stages of his artistic activity, he experimented with other areas of art in search of a medium that would allow him to fulfil his creative potential. Avidan's activity manifested itself in many fields: he found fulfillment in the theatre, ran his radio and television programs, released an album with the recitation of his po-
[13] S. Pinsker, Hebrew Literature, [in:] The Cambridge History of Judaism. Volume VIII: The Modern World, 1815-200o, Cambridge 2017, p. 770.
[14] A. Weisman, op.cit., pp. 12-13. 
ems, and, most importantly, created a few visual arts and film projects. Before the production of Message from the future, Avidan had several short films to his credit, which attracted the attention of audiences not only in Israel, but also abroad. For example, the scandalous short film Sex, made in 1970, was even screened at the Cannes Film Festival[15]. Nevertheless, in Israel, the provocative 26-minute picture, which combined bold erotic scenes with Judaic and Christian symbolism, was banned for offending morals and religious values. Sex well illustrates that Avidan, as a genuinely multimedia creator, was in constant search of fresh ground, on which he cultivated the rebellious and avant-garde nature of his art.[16]

In the context of Message from the future, it is necessary to mention Avidan's passion, which undoubtedly influenced the final shape of the film. Avidan repeatedly admitted his fascination with science fiction, which was a source of inspiration and artistic stimulation for him. In a 1963 interview, he declared: "[...] a science fiction work, of little literary value, may stimulate me in a way that a poem by Eliot cannot. [...] We face the unknown, fervently trying to decode developments and sensations that previous generations of modern authors never thought to consider." [17] His poetry is full of references to classic science fiction themes, and he consciously used the motifs attributed to SF literature, then commonly regarded as unsophisticated. It was another tool allowing him to emphasize his distinctiveness from mainstream Hebrew literature. In his poems, we find futuristic inventions, interstellar journeys, black holes, and time travel.[18] Avidan was also fascinated by modern technology, which became a source of inspiration and the material of his art. The best example was the book My Electronic Psychiatrist: Eight Authentic Talks with a Computer, published in 1974, a record of therapeutic conversations Avidan had with ELIZA, MIT's computer program simulating a psychoanalyst. The fascination with technology and speculative fiction also, to some extent, shaped the media and artistic image of Avidan, who liked to spread fantastic information about his origin. He repeatedly claimed that he came from a distant future, and sometimes he posed as an alien from another planet, calling himself a galactic poet.[19] He considered his stay in Israel the result of a forced landing, which made him adapt to the limitations of terrestrial life, methods of communication, and means of creation. Therefore, it is not surprising that the only feature-length film he ever made referred to the poetics of SF, taking full advantage of the tradition of this genre.

[15] A. Vogel, Film as a Subversive Art, New York 2005, p. 231.

[16] Y. Dahan, The Films of Israeli Poet and Enfant Terrible David Avidan, 2019, <https://mubi.com/ notebook/posts/the-films-of-israeli-poet-and-enfantterrible-david-avidan>, accessed: 17.03.2020.
[17] As cited in: A. Weisman, op.cit., p. 17. [18] E. Eshed, Ha-Ish Sheba Mehatid, 200o, <https:// www.sf-f.org.il/sf-f/old_site/story_33.html>, accessed: 2.01.2020.

[19] A. Weisman, op.cit. 
Reversed Klaatu
At the most literal level, Message from the future tells the story of a supposed emissary from the thirtieth century (played by Dutch actor Joseph Bee), who arrives in 1985, shortly after Israel officially joined the club of nuclear powers. A visitor calling himself Futureman (FM, for short), instructed by his superior (played by Avidan himself), visits the past with a very unusual mission. Using telepathic technology, he wants to convey to humanity the message about the necessity of unleashing a global conflict because "all wars have broken out too late." FM calls on the nations of the globe to prepare for a worldwide nuclear conflagration that will cleanse the world, as postponing matters is considered an archaic behaviour in his day. To persuade the international community, he replicates himself into seven identical copies, which he sends out to the world's major metropolises (one of which is Tel Aviv). He takes control of the media, changing the headlines of major newspapers and encroaching on TV screens. He speaks through telepathy in many languages; his message becomes truly global. In one of the film's final acts, he almost manages to convince the leaders of the UN Security Council to implement his gruesome plan. On the way to accomplishing this mission, he meets no great resistance, except for the opposition of a single Israeli scientist.

It is worth noting here that the story described above can be read as a kind of reversal of the meanings and plots of classic Hollywood science fiction cinema from the 1950s, the period of the most significant Cold War tension and escalation of fears related to the threat of nuclear weapons. The dropping of atomic bombs on Hiroshima and Nagasaki opened to American filmmakers a whole gallery of new motifs and metaphors reflecting common fears of that time. Susan Sontag aptly diagnosed this phenomenon in her famous essay, "The Imagination of Disaster". Sontag rightly noted that the collective imagination was then overwhelmed by the widespread trauma of nuclear weapons and the possibility of a nuclear war. Most science fiction movies were testimony to this trauma and somehow tried to deal with it.[20] The screens were full of visions of nuclear apocalypses destroying the Earth (e.g., On the Beach, dir. Stanley Kramer, 1959), or extraterrestrial invasions threatening humanity with technologically advanced weapons of mass destruction (e.g., The War of the Worlds dir. Byron Haskin, 1953). There were also stories expressing fears about the negative effects of radiation as a tool in the hands of an alien civilization (e.g., Invaders from Mars, William Cameron Menzies, 1953), or as a cause of mutations transforming people or animals into terrifying monsters (e.g., Them!, dir. Gordon Douglas, 1954). Jerome Shapiro notes that most of these films, which he classifies as "Atomic Bomb Cinema," are the most recent manifestation of the ancient apocalyptic tradition of continuance[21]. The
[20] S. Sontag, The imagination of disaster, [in:] Hibakusha Cinema. Hiroshima, Nagasaki and the Nuclear Image in Japanese Film, ed. by M. Broderick, New

York 2009, p. 46.
[21] J.F. Shapiro, Atomic Bomb Cinema. The apocalyptic imagination on film, New York 2002. 
filmmakers (more or less consciously) used structures borrowed from myths, legends and religious accounts to explain the disturbing events of their day. However, none of the films made at the time did so more openly than Robert Wise's memorable The Day the Earth Stood Still (1951), which was undoubtedly Avidan's main cinematic inspiration.

Wise's film, similarly to Message from the future, tells the story of an envoy of a highly-advanced civilization (in this case an extraterrestrial one) who comes to our planet to carry out a mission on which the existence of mankind depends. An alien named Klaatu (Michael Rennie) lands on our planet to convince world leaders to eradicate nuclear weapons, which are a threat to the entire galaxy. However, the space visitor meets with a lack of understanding from the majority of the Earthlings, who repeatedly assure him that gathering the leaders of the hostile Cold War camps in one place is impossible. After many difficulties, thanks to the help of the boy Bobby (Billy Gray), his mother (Patricia Neal) and the genius professor Barnhardt (Sam Jaffe), he manages to present his message to a group of the most eminent scientists from around the world. He then delivers a dangerous ultimatum: either humanity will get rid of the deadly weapon and join the interplanetary community of peace, or it will be annihilated. The story of Klaatu was often read in a religious key, in which the protagonist is identified with the figure of Christ.[22] Klaatu, like Jesus, faces rejection, gathers a group of faithful disciples around him, is murdered, and then rises to present mankind with an offer of a peaceful covenant. Figures of cosmic messiahs have repeatedly returned to American science fiction; good examples of this are the novels "Stranger in a Strange Land" by Robert A. Heinlein and "The Man Who Fell to Earth" by Walter Tevis, in which this phenomenon has been thoroughly deconstructed. There are clear echoes of this tradition in Avidan's work.

It is not difficult to see the similarities between Klaatu and Futureman; they are visible both on the visual level (e.g. they both appear to mankind in a shiny metallic suit) and in numerous narrative convergences. Both FM and the protagonist of Wise's film operate on a global scale; they want to present their demands to the representation of Earth's authorities. To achieve this goal, they use highly-advanced technology in a spectacular way: Klaatau disconnects most of the planet from electricity, Futureman takes control of the mass media and uses telepathic transmitters to contact people in all corners of the globe. In the final acts of their stories, they both appear in front of an international group of representatives of planet's nations - Klaatu in the presence of eminent scientists, Futureman in the front of world's most powerful politicians. However, the parallels end there. While Klaatu wants to force humans into permanent peace through the threat of

[22] See: K. Gabbard, Religious and political allegory in Robert Wise's: "The Day The Earth Stood Still,"

"Literature/Film Quarterly" 1982, vol. 10, no. 3, pp. 150-153; A.K. Kozlovic, Robert Wise's The Day the
Earth Stood Still Part I: A Religious Film?, "Kinema: A Journal for Film and Audiovisual Media" 2013, no. 40, pp. 4-30. 
an imminent apocalypse, Futureman urges the audience to let go of their fear and joyfully embark on a devastating war. In Avidan's vision, nuclear destruction ceases to be a threat; it becomes a promise of a better tomorrow, foreshadowing the coming of a new, bright future. This inversion of Klaatu's and Futureman's intentions is crucial to the interpretation of Message from the future.

It should be mentioned at this point that nuclear weapons are one of the main leitmotifs continuously appearing in Avidan's film. The entire movie is filled with smaller or larger references to the atomic bomb and the dangers of having access to it. It is no coincidence that the director begins his story in the near future, in the year of the first official Israeli nuclear tests in the Sinai Peninsula. In the mid-1980s, the world is on the brink of nuclear conflict and tensions between the USSR and the West increase, while a new hawkish government comes to power in Germany. The subject of the possible war is reinforced by the radio and TV broadcasts that return to the screen from time to time. In these circumstances, the Israeli bomb becomes the next step to the outbreak of war. However, Israel's official accession to the Club of Nuclear Powers is not the only motif related to this topic. It is no coincidence that the CEO of a great Japanese high-tech corporation (played by Kiichi Sasayama), who is key to the film's most significant plot twist, has the meaningful name of Hiroshi. From this point of view, some first shots of the film are also relevant. The camera shows the towers of the Koffler Accelerator, an architectural symbol of the Weizmann Institute, one of the leading Israeli research centres. In the world of film, this unique formalist building pretends to be a technically advanced time machine, thanks to which FM moves to 1985. However, the use of this recognizable structure enriches the film with another clue related to nuclear energy, because the Weizmann Institute was one of the first Israeli institutions dealing with the development of this technology.[23]

Avidan's strong emphasis on any nuclear-related content is vital and deeply-rooted in reality. It should be noted at this point that when Avidan was creating the Message from the future, the issue of the existence of a potential Israeli atomic bomb had been the subject of public debate for a long time. Israel's complicated geopolitical situation made the possession of a nuclear weapon a raison d'etat and one of the essential military goals. For decades, Israeli politicians had specialized in sending ambiguous messages about a potential nuclear arsenal, like a mantra repeating a sentence that "Israel will not be the first country to introduce nuclear weapons in the Middle East." However, the perennial policy of deliberate ambiguity turned the existence of Israeli bomb into an open secret that has never been officially confirmed. Maintaining this state of affairs was caused by factors of a military-diplomatic nature. It had little to do with the views of Israeli society, which was enthusiastic

[23] W.D. Farr, The Third Temple's Holy of Holies. Israel's Nuclear Weapons, Farr W.D., The Third Temple's
Holy of Holies. Israel's Nuclear Weapons, Montgomery 1999, pp. 2-3. 
about the Israeli bomb. In 1976, the Ha-aretz published the results of a sociological study on the position of Israelis on the probable existence of an Israeli nuclear arsenal. Sixty-two percent of those polled believed their nation had nuclear weapons; seventy-seven thought that if it did not already have it, it should. Only four percent thought Israel was nuclear-weapon-free.[24] Thus, in public consciousness, the Israeli bomb was not related to the fear of nuclear annihilation, but the hope of stabilizing the position of the Jewish State in a hostile international environment.

There is, therefore, an interesting shift in Avidan's film; the anxiety, fears and paranoia of atomic bomb that filled 1950s SF movies are replaced with the enthusiastic acceptance of the new weapon. With his characteristic irony, the artist paints a distorted portrait of Israelis who, like the character of Kubrick's memorable film learned to stop worrying and love the bomb. The film outlines a clear satire on the attitude of Israeli society to nuclear weapons; the characters of Message from the Future do not notice the dangers of the bomb in their delight over their acquired military capabilities. Futureman's supervisor, played by Avidan himself, welcomes the nuclear explosion on Sinai with an exited telepathic message: The pushiest, craziest, sanest, profanest, holiest, sacredest, luckiest! Numerous radio and TV news reports informing about this event are also noticeably enthusiastic. Evident satisfaction with the success of the nuclear experiment is likewise expressed by Dr Dan Ziv (Avi Yakir), the Israeli scientist who is the main antagonist of Futureman. The film's omnipresent admiration for weapons of mass destruction is most fully expressed in one of the scenes, when a singer, dressed in a futuristic jumpsuit, sings a provocative song written by Avidan:

Radioactivity is a hell of an activity

Subatomic reaction is a right kind of action

We live in Tel Aviv and we live in the mushroom

That just what we are

The character of Dr Ziv is yet another example of how much Message from the future deconstructs classic SF structures to comment on Israeli reality. As Cyndy Hendershot notes, in the post-war period, a new type of scientist emerged in the centre of cultural interest: the nuclear scientist responsible for the success of the Manhattan Project.[25] In the SF cinema of the 50s, these characters began to be portrayed as the possessors of secret knowledge, intelligence and sensitivity that would save the Earth from their destructive tendencies. In films such as This Island Earth (dir. Joseph M. Newman, 1955) or Killers from Space (dir. W. Lee Wilder 1954), nuclear scientists became the last resort in situations of the most significant threat. We can observe a similar relationship in The Day the Earth Stood Still. In Wise's film,

[24] As cited in: M. Wagner, Recipe for an Israeli nuclear arsenal, "Middle East Report" 1986, no. 143, p. 9.
[25] C. Hendershot, Paranoia, the Bomb, and 1950 s Science Fiction Films, Bowling Green 1999, p. 23. 
Klaatu's messianic legation is opposed by politicians and the military. His mission is aptly recognized by only a handful of heroic Americans, of whom the most important is Dr Jacob Barnhardt, a character who, by his appearance, shows a considerable resemblance to Albert Einstein. Barnhardt takes on the role of the cosmic Messiah's faithful disciple and, together with an international group of intellectuals, provides leadership in times of crisis.

The character played by Avi Yakir is very different from Dr Barnhardt from The Day the Earth Stood Still. He is not an aged scientist who spent his days figuring out complicated mathematical formulas. On the contrary, he is a handsome young playboy who is continuously adored by women (who are frequently naked). His expressive image of a macho male can be read as a caricature of the vital model of masculinity inscribed into the Israeli culture. It is worth noting that Ziv is not only a scientist but also another screen incarnation of Sabra, a figure of a New Jew born in the land of his ancestors.[26] Sabra, as a product of Zionism, was a contradiction to all values associated with the times of the diaspora. He was not to humbly endure humiliation, but to actively fight for his and his nation's survival. No wonder that after Israel regained independence, the figure of Sabra fused with the image of an Israeli soldier. Over the decades, this image was actively preserved, among others, by Israeli cinema in films classified by Ella Shohat as the heroic-nationalist genre.[27] Dr Ziv follows this tradition because, in addition to being a scientist, he is also an officer in the army. In several scenes, we can see him in an IDF uniform, which not only makes him blend in with the Israeli landscape, but also clearly distinguishes him from the characters of scientists from the aforementioned classic SF movies. The model taken from Wise's film is clearly deconstructed. While in The Day the Earth Stood Still, scientists opposed the military establishment, in Message from the future, they are an important part of it. The element of Ziv's ethos as Sabra must also be Israeli militarism with all its implications. So the image of the scientist in Avidan's film is adapted to local conditions and Ziv as an Israeli cannot oppose the Israeli bomb.

As an antagonist of Futureman, however, Ziv recognizes the danger that FM activities bring to the world and decides to oppose him. For a while, driven by national interests, he welcomes the Israeli nuclear arsenal, but consciously does not accept the future's plan to start the Third World War. The confrontation between Ziv and Futureman takes place on the forum of the UN Security Council, where FM, using telepathic devices, arouses enthusiasm for war among the gathered world leaders. This meeting is a direct reference to the scene of Klaa-

[26] U. Klein, Our best boys: The making of masculinity in Israeli society, [in:] Male Roles, Masculinities and Violence: A culture of peace perspective, ed. by I. Breines, R. Connell, and I. Eide, Paris 200o, pp. 163-80; O. Almog, The Sabra. The Creation of the New Jew, Berkeley, Los Angeles, London 2000. [27] E. Shohat, Israeli Cinema. East/West and the Politics of Representation, London, New York 2010. 
tu's farewell to Earth, in which the alien communicated his message to scientists from all over the world. In The Day the Earth Stood Still, the encounter of an extraterrestrial visitor with the greatest minds of the planet, which crowns the story, makes viewers aware of the great responsibility and threat related to Klaatu's mission. In Avidan's film, however, another deconstruction occurs. Ziv's heroic fervor is quickly extinguished as the telepathic duel between him and FM turns out to be only part of a large-scale, incredibly imaginative publicity gimmick. From short media news broadcast, we learn that the story of the emissary from the future was merely a marketing trick planned by a huge Japanese corporation. The media hype surrounding the alleged time traveller was, in fact, an advertising campaign for a new technological gadget that allows communication via telepathy. With this puckish twist, the director finally deconstructs the plot structure known to the viewer: it turns out that the stakes were never high, the threat did not exist, and all Ziv's actions were pointless from the very beginning. There were no villains or heroes in this story; the logic of capitalism was behind everything.

It is difficult to unequivocally judge whether this unexpected ending was also a commentary on the reality of the time, as, in the early 1980 s, Israel was only at the beginning of the neoliberal path that it followed after years of the statist and interventionist policy of the Labor Party. It was also just the beginning of a robust internationalization of the Israeli economy, which was to increase in the following years. However, the clue leading to reading the film as a diagnosis of neoliberal changes does not seem to be groundless. It seems no accident that the only real politician appearing on the screen is Margaret Thatcher (played by Pam Barden), who was one of the main eulogists of neoliberal transformations. It is worth noting here that capitalism, as the dynamic force capable of changing the world, enthralled Avidan, who often treated his art as (frequently unsuccessful) business initiatives. Analyzing this aspect of Avidan's literary work, Anat Weisman concluded: "Avidan's poetry poses for the ongoing discussion on creativity, art, self-destructive capitalism, and financial irresponsibility as the existential drama of our present world, which seems to believe in no progress but the technological one." [28]

Echoes of these tendencies seem to resonate in the final act of Message from the future. From this perspective, Futureman becomes a figure embodying the expanding processes of economic and media globalization. A major metamorphosis made by the director in the borrowed SF narrative is revealed here. In Avidan's vision, the Cold War paradigm that organizes the diegesis of the anti-nuclear movies of the 1950 s becomes obsolete. To the viewer's surprise, it is replaced

[28] A. Weisman, The poet as entrepreneur: The case

of David Avidan, "Dibur Literary Journal" 2018, no. 5, p. 30 . 
by the logic of neoliberal globalization organized by technological development and profit-oriented enterprises, not ideological and geopolitical divisions. In this world, nuclear weapons are losing the dread they raised several decades earlier.

It is hard to deny the director an accurate intuition; after all, the end of the Cold War and the world domination of neoliberal doctrine became a reality a decade later. Avidan, however, could not predict the future (which was sometimes attributed to him), as evidenced by the film's failure. As a result, Message from the future was the last film he ever directed, as none of the cinematic projects he announced ever saw the light of day. The movie will always remain the most ambitious of the audiovisual works of the director-poet who, despite his fascination with the future, created the picture that is today one of the most eccentric testimonies of its time: a forgotten message from the past.

Almog O., The Sabra. The creation of the New Jew, Berkeley, Los Angeles, London 2000

Ariel N., How to do things with futurism: Traces of futurism in Hebrew culture, "Modernism/Modernity" 2020, vol. 27, no. 1, pp. 1-26

Avidan D., Message from the Future, [in:] Futureman, transl. by T. Keller, Los Angeles 2017, pp. 135-136

Ben-Yehuda N., Hebrew SF, [in:] Anatomy of Wonder. A Critical Guide to Science Fiction, ed. by N. Barron, New York, London 1987, pp. 577-582

Ben-Yehuda N., Sociological reflections on the history of science fiction in Israel, "Science Fiction Studies" 1986, vol. 13, no. 38, pp. 64-78

Cohen A., The Worst-Kept Secret: Israel's bargain with the bomb, New York 2010

Crawley T., Message from the Future, "Starburst Magazine" 1981, vol. 4, no. 3, pp. $16-18$

Dahan Y., The films of Israeli poet and enfant terrible David Avidan, 2019, <https:// mubi.com/notebook/posts/the-films-of-israeli-poet-and-enfant-terrible-david-avidan>, accessed: 17.03.2020

Eshed E., Ha-Ish Sheba Mehatid, 2000, <https://www.sf-f.org.il/sf-f/old_site/story_33.html>, accessed: 2.01.2020

Farr W.D., The Third Temple's Holy of Holies. Israel's Nuclear Weapons, Montgomery 1999

Gabbard K., Religious and political allegory in Robert Wise's: "The Day The Earth Stood Still," "Literature/Film Quarterly" 1982, vol. 10, no. 3, pp. 150-153

Hendershot C., Paranoia, the Bomb, and 1950s Science Fiction Films, Bowling Green 1999

Kaplan E., Projecting the Nation. History and Ideology on the Israeli Screen, New Brunswick 2020

Klein U., Our best boys: The making of masculinity in Israeli society, [in:] Male Roles, Masculinities and Violence: A culture of peace perspective, ed. by I. Breines, R. Connell, I. Eide, Paris 2000, pp. 163-180

Kozlovic A.K., Robert Wise's The Day the Earth Stood Still Part I: A Religious Film?, "Kinema" 2013, no. 40, pp. 4-30

Kozlovic A.K., Robert Wise's The Day the Earth Stood Still (Part II), "Kinema” 2014, no. Spring 
Kozlovic A.K., Robert Wise's The Day the Earth Stood Still (Part III), "Kinema" 2014, no. Fall

Kronfeld C., Harshav's Likrat: Toward a new poetics and politics of the "Statehood Generation," "Dibur Literary Journal” 2016, no. 2, pp. 90-97

Manor G., Mada Bizyoni, "Al HaMishmar", 10.09.1981, p. 6

May A., Rockets and Ray Guns: The Sci-Fi Science of the Cold War, Crewkerne 2018

Nativ T., Avidan Magiya Min ha-atid, "Davar”, 13.02.1981, p. 21

Nicholls P., The World of Fantastic Films, New York 1984

O'Donnell V., Science ficton films and Cold War anxiety, [in:] Transforming the Screen 1950-59, ed. by P. Lev, New York 2003, pp. 169-195

Omry K., Israeli SF 101, "SFRA Review 2013, no. 306, pp. 8-11

Pinsker S., Hebrew literature, [in:] The Cambridge History of Judaism. Volume VIII: The Modern World, 1815-2000, Cambridge 2017, pp. 755-776.

Seed D., American Science Fiction and the Cold War. Literature and film, Chicago, London 1999

Shapiro J.F., Atomic Bomb Cinema. The apocalyptic imagination on film, New York 2002

Shippey T., The Cold War in science fiction, 1940-1960, [in:] Popular Culture: Past and Present, ed. by B. Waites, T. Bennett, and M. Graham, London, New York 1982, pp. 308-322

Shohat E., Israeli Cinema. East/West and the Politics of Representation, London, New York 2010

Sontag S., The imagination of disaster, [in:] Hibakusha Cinema. Hiroshima, Nagasaki and the Nuclear Image in Japanese Film, ed. by M. Broderick, New York 2009, pp. 38-53

Teitelbaum S., Israel, [in:] The Encyclopedia of Science Fiction, ed. by J. Clute and P. Nicholls, New York 1993, pp. 629-630

Teitelbaum S., Lottem E., Introduction, [in:] Zion's Fiction: A Treasury of Israeli Speculative Literature, ed. by S. Teitelbaum and E. Lottem, Simsbury 2018

Vogel A., Film as a Subversive Art, New York 2005

Wagner M., Recipe for an Israeli nuclear arsenal, "Middle East Report" 1986, no. 143, pp. 8-12, 14-15.

Weisman A., David Avidan: The sadosemantic Poet, [in:] Futureman, ed. by T. Keller, Los Angeles 2017, pp. 9-23

Weisman A., The Poet as Entrepreneur: The Case of David Avidan, "Dibur Literary Journal" 2018, no. 5, pp. 21-30 